\title{
Cellular Bioenergetics after Erythropoietin Therapy in Chronic Renal Failure
}

\author{
Ramon M. Marrades, ${ }^{\star}$ Juli Alonso, ${ }^{\ddagger}$ Josep Roca, ${ }^{\star}$ Jose M. González de Suso, ${ }^{\ddagger}$ Josep M. Campistol, ${ }^{\star}$ Joan A. Barberà, ${ }^{*}$ \\ Orlando Diaz, ${ }^{*}$ Josep V. Torregrosa, ${ }^{\star}$ Joan R. Masclans, ${ }^{*}$ Robert Rodríguez-Roisin, ${ }^{\star}$ and Peter D. Wagner ${ }^{\S}$ \\ * Servei de Pneumologia i Al.lèrgia Respiratòria, Unitat de Transplantament Renal, Hospital Clínic, Universitat de Barcelona 08036, \\ ${ }^{\ddagger}$ Centre Diagnòstic Pedralbes, Barcelona; Centre d’Alt Rendiment, Sant Cugat del Vallés, Spain; and ${ }^{\S}$ Department of Medicine, \\ Section of Physiology, University of California, San Diego. La Jolla, California 92093-0623
}

\begin{abstract}
After erythropoietin (rHuEPO) therapy, patients with chronic renal failure (CRF) do not improve peak $\mathrm{O}_{2}$ uptake $\left(\mathrm{V}_{2}\right.$ peak) as much as expected from the rise in hemoglobin concentration ([Hb]). In a companion study, we explain this phenomenon by the concurrent effects of fall in muscle blood flow after rHuEPO and abnormal capillary $\mathrm{O}_{2}$ conductance observed in CRF patients. The latter is likely associated with a poor muscle microcirculatory network and capillary-myofiber dissociation due to uremic myopathy. Herein, cellular bioenergetics and its relationships with muscle $\mathrm{O}_{2}$ transport, before and after rHuEPO therapy, were examined in eight CRF patients $(27 \pm 7.3$ [SD] yr) studied pre- and post-rHuEPO $([\mathrm{Hb}]=7.8 \pm 0.7$ vs. $11.7 \pm 0.7 \mathrm{~g} \times \mathrm{dl}^{-1}$ ) during an incremental cycling exercise protocol. Eight healthy sedentary subjects $(26 \pm 3.1 \mathrm{yr})$ served as controls. We hypothesize that uremic myopathy provokes a cytosolic dysfunction but mitochondrial oxidative capacity is not abnormal. ${ }^{31} \mathrm{P}$-nuclear magnetic resonance spectra $\left({ }^{31} \mathrm{P}\right.$-MRS) from the vastus medialis were obtained throughout the exercise protocol consisting of periods of 2 min exercise (at $1.67 \mathrm{~Hz}$ ) at increasing workloads interspersed by resting periods of $2.5 \mathrm{~min}$. On a different day, after an identical exercise protocol, arterial and femoral venous blood gas data were obtained together with simul-

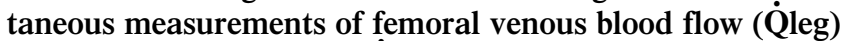
to calculate $\mathrm{O}_{2}$ delivery $\left(\dot{\mathrm{Q}}_{2} \mathrm{leg}\right)$ and $\mathrm{O}_{2}$ uptake $\left(\dot{\mathrm{V}}_{2} \mathrm{leg}\right)$. Baseline resting [phosphocreatine] to [inorganic phosphate] ratio $([\mathrm{PCr}] /[\mathrm{Pi}])$ did not change after $\mathrm{rHuEPO}(8.9 \pm 1.2 \mathrm{vs.}$ $8.8 \pm 1.2$, respectively), but it was significantly lower than in controls $(10.9 \pm 1.5)(P=0.01$ each $)$. At a given submaximal or peak $\dot{\mathrm{VO}}_{2}$ leg, no effects of rHuEPO were seen on cellular bioenergetics $([\mathrm{PCr}] /[\mathrm{Pi}]$ ratio, \%[PCr] consumption, halftime of [PCr] recovery after exercise), nor in intracellular $\mathrm{pH}$ (pHi). The post-rHuEPO bioenergetic status and $\mathrm{pHi}$, at a given $\dot{\mathrm{V}}_{2}$ leg, were below those observed in the control group. However, at a given $\mathrm{pHi}$, no differences in ${ }^{31} \mathrm{P}$-MRS data were detected between post-rHuEPO and controls. After rHuEPO, at peak $\dot{\mathrm{V}}_{2}$, Q̀leg fell $20 \%(P<0.04)$, limiting
\end{abstract}

Address correspondence to Josep Roca, MD, Servei de Pneumologia, Hospital Clínic, Villarroel 170, Barcelona 08036, Spain. Phone: 343227-5540; FAX: 343-227-5455; E-mail: roca@medicina.ub.es

Received for publication 7 September 1995 and accepted in revised form 5 March 1996.

J. Clin. Invest.

(C) The American Society for Clinical Investigation, Inc.

0021-9738/96/05/2101/10 \$2.00

Volume 97, Number 9, May 1996, 2101-2110 the change in $\dot{\mathbf{Q O}}_{2}$ leg to $+17 \%$, a value that did not reach statistical significance. The corresponding $\mathrm{O}_{2}$ extraction ratio decreased from $73 \pm 4 \%$ to $68 \pm 8.2 \%(P<0.03)$. These changes indicate that maximal $\mathrm{O}_{2}$ flow from microcirculation to mitochondria did not increase despite the $50 \%$ increase in $[\mathrm{Hb}]$ and explain how peak $\dot{\mathrm{V}}_{2}$ leg and cellular bioenergetics $\left({ }^{31} \mathrm{P}-\mathrm{MRS}\right)$ did not change after rHuEPO. Differences in $\mathrm{pHi}$, possibly due to lactate differences, between post-rHuEPO and controls appear to be a key factor in the abnormal muscle cell bioenergetics during exercise observed in CRF patients. (J. Clin. Invest. 1996. 97:2101-2110.) Key words: energy metabolism • exercise $\bullet$ muscle $\mathrm{O}_{2}$ transport • oxygen transport $\cdot \dot{\mathrm{V}} \mathrm{O}_{2} \mathrm{max}$

\section{Introduction}

It is known that substantial increases in hemoglobin concentration $([\mathrm{Hb}])^{1}$ after erythropoietin (rHuEPO) therapy in patients with chronic renal failure (CRF) are not followed by corresponding gains of maximum $\mathrm{O}_{2}$ uptake $\left(\dot{\mathrm{V}} \mathrm{O}_{2} \max \right)(1-9)$. In a previous study with CRF patients (10), $\mathrm{O}_{2}$ supply dependency of $\dot{\mathrm{V}} \mathrm{O}_{2}$ max was demonstrated. This indicates that peak $\dot{\mathrm{V}} \mathrm{O}_{2}$ is not determined by mitochondrial oxidative limits. The dissociation between increase in $[\mathrm{Hb}]$ and the changes of $\dot{\mathrm{V}} \mathrm{O}_{2}$ max after $\mathrm{rHuEPO}$ was explained by two factors affecting $\mathrm{O}_{2}$ transport to the cell.

First, correction of anemia with rHuEPO therapy results in elimination of the hyperdynamic cardiac status. This returns elevated muscle blood flow $(\dot{Q})$ to values similar to levels seen in matched control subjects during peak exercise and partially offsets the effect of the rise in arterial $\mathrm{O}_{2}$ content on $\mathrm{O}_{2}$ delivery. Second, $\mathrm{O}_{2}$ conductance from muscle microcirculation to mitochondria is particularly low in CRF patients (10) and after rHuEPO therapy still remains at $\sim 70 \%$ of that seen in control subjects. The structural basis of this abnormal $\mathrm{O}_{2}$ transport conductance is likely microvascular rarification and capillarymyofiber dissociation provoked by a uremic myopathy (1113). As a result of these changes, the ratio of muscle diffusive to perfusive conductance as defined by Piiper et al. (14-16) may either not vary (10) or even fall after rHuEPO. Since this

1. Abbreviations used in this paper: $\mathrm{CaO}_{2}$, arterial $\mathrm{O}_{2}$ content; $\mathrm{C}_{\mathrm{fv}} \mathrm{O}_{2}$, femoral venous $\mathrm{O}_{2}$ content; $\mathrm{DO}_{2}$, muscle $\mathrm{O}_{2}$ conductance from the capillary to the mitochondria; $[\mathrm{Hb}]$, hemoglobin concentration; MVC, maximal voluntary contraction; $[\mathrm{PCr}] /[\mathrm{Pi}]$, ratio of [phosphocreatine] to [inorganic phosphate]; \%[PCr] consumption, phosphocreatine) consumption during exercise expressed as percent of phosphocreatine at rest, measured before each exercise step; pHi, intracellular $\mathrm{pH} ; \dot{\mathrm{Q}}_{2}$ leg, one-leg $\mathrm{O}_{2}$ delivery; rHuEPO, recombinant human erythropoietin; $\dot{\mathrm{VO}}_{2}$, whole-body $\mathrm{O}_{2}$ uptake; $\dot{\mathrm{V}} \mathrm{O}_{2}$ leg, one-leg $\mathrm{O}_{2}$ uptake. 
ratio determines $\mathrm{O}_{2}$ extraction by muscle, post-rHuEPO $\mathrm{O}_{2}$ extraction would not change or may fall (17).

We hypothesize that, in addition to the muscle $\mathrm{O}_{2}$ transport problem described above, post-rHuEPO muscle bioenergetic status at a given $\dot{\mathrm{V}} \mathrm{O}_{2}$, as reflected by [phosphocreatine] to [inorganic phosphate] ratio $([\mathrm{PCr}] /[\mathrm{Pi}])$ at rest and during exercise, $\%[\mathrm{PCr}]$ consumption during exercise, and half-time of $[\mathrm{PCr}]$ recovery after exercise, is below the values observed in normal sedentary subjects. This defect in muscle cell bioenergetics may be explained by a cytosolic dysfunction provoked by uremic myopathy. Since evidence of normal mitochondrial oxidative capacity in CRF patients has been reported $(11,18)$, and the companion study showed that $\dot{\mathrm{V}} \mathrm{O}_{2}$ peak is $\mathrm{O}_{2}$ supply dependent in these rHuEPO treated patients, changes in muscle bioenergetics at maximum exercise after $\mathrm{rHuEPO}$ therapy must follow those of maximal $\mathrm{O}_{2}$ flow from muscle capillary to mitochondria. However, different reports examining muscle cell bioenergetics in these patients provide conflicting results (18-22). The primary aim of the present study was the analysis of the relationships between muscle $\mathrm{O}_{2}$ transport and cellular bioenergetics, assessed by ${ }^{31} \mathrm{P}$-nuclear magnetic resonance spectroscopy ( $\left.{ }^{31} \mathrm{P}-\mathrm{MRS}\right)$, before and after erythropoietin therapy. Post-rHuEPO data were compared with those obtained in healthy sedentary subjects. Because we were specifically interested in the analysis of muscle $\mathrm{O}_{2}$ transport and ${ }^{31} \mathrm{P}-\mathrm{MRS}$ data at maximum $\dot{\mathrm{V}} \mathrm{O}_{2}$, the exercise protocol was set to explore exercise performance above $70 \%$ whole-body $\dot{\mathrm{V}} \mathrm{O}_{2}$ peak.

\section{Methods}

Patients. Eight anemic subjects (age $27 \pm 7.3$ [mean \pm SD] yr), seven men and one woman, with chronic renal failure undergoing regular hemodialysis for an average of $12 \pm 11 \mathrm{mo}$, were enrolled in the proto- col and studied pre- and post-rHuEPO therapy. Anthropometric, lung function data, adequacy of hemodialysis, and hemoglobin concentration $[\mathrm{Hb}]$ before and after rHuEPO therapy using standard dosage $\left(82 \pm 12 \mathrm{UI} \times \mathrm{kg}^{-1} \times \mathrm{wk}^{-1}\right)$ are listed in Table I. Eight additional healthy sedentary men, selected on the basis of no previous history of regular or even occasional physical exercise above that required for the average daily activities, were also studied once using an identical protocol and were used as a control group (Table I). All were informed of any risks and discomfort associated with the experiment, and informed consent was obtained in accordance with the Committee on Investigations Involving Human Subjects at the Hospital Clínic, Universitat de Barcelona. None of these subjects were the same individuals examined in the accompanying paper (10).

Exercise protocol. Exercise tests were performed using an ergometer made of nonmagnetic materials conceived to fit into a standard whole body magnet. The system, described in detail in reference 24, allowed flexion and extension of both legs by alternatively pressing two foot pedals connected to a controlled flow resistance hydraulic system while the subject lay supine on the ergometer table. A piezoelectric force transducer (9251A; Kistler Instruments AG, Winterthur, Switzerland) placed inside one of the pedals was used to determine maximum force of contraction (maximal voluntary contraction, MVC) of the leg and to provide an "on line" control of both strength and rate of pedalling during the exercise test. The exercise protocol, performed at 100 cycles $\times \min ^{-1}$, consisted of a maximum of 5 periods of 2 min exercise at workloads of 20, 25, 30, 35, and 40\% of MVC interspersed by resting periods of $2.5 \mathrm{~min}$. Each subject's MVC was calculated as the mean of three measurements. It should be pointed out that the above mentioned percentages of MVC greatly exceed the corresponding values of $\mathrm{VO}_{2}$. As reported below, the work load at $20 \%$ MVC corresponded to a whole-body $\dot{\mathrm{V}}_{2}$ value above $70 \%$ of maximum. In each exercise test, the peak workload was defined by the inability to maintain for $30 \mathrm{~s}$ the rate of pedalling due to exhaustion.

Study design. In each study, the patient exercised breathing room air $\left(\mathrm{F}_{\mathrm{I}} \mathrm{O}_{2}=0.21\right)$ on two different days, less than $1 \mathrm{wk}$ apart, using the same ergometer and performing the same exercise protocol. On the

Table I. Anthropometric Data, Lung Function, Adequacy of Dialysis, and Changes in Hemoglobin Concentration

\begin{tabular}{|c|c|c|c|c|c|c|c|c|c|c|c|c|c|c|}
\hline \multirow[t]{2}{*}{ Subject } & \multirow{2}{*}{$\begin{array}{c}\text { Age } \\
y r\end{array}$} & \multirow{2}{*}{$\begin{array}{c}\text { Height } \\
\mathrm{cm}\end{array}$} & \multirow{2}{*}{$\begin{array}{c}\text { Weight } \\
\mathrm{kg}\end{array}$} & \multicolumn{2}{|c|}{$\mathrm{FEV}_{1}$} & \multirow{2}{*}{$\begin{array}{c}\mathrm{FEV}_{1} / \mathrm{FVC} \\
\%\end{array}$} & \multirow{2}{*}{$\frac{\mathrm{PaO}_{2}}{\mathrm{mmHg}}$} & \multirow{2}{*}{$\frac{\mathrm{Kt} / \mathrm{V}}{\text { urea }}$} & \multirow{2}{*}{$\frac{\text { PCR }}{g \cdot k^{-1} \cdot d a y}$} & \multirow{2}{*}{$\frac{\mathrm{HD}}{h \cdot W^{-1}}$} & \multirow[t]{2}{*}{ Dialyzer } & \multirow{2}{*}{$\frac{[\mathrm{Hb}]}{\text { pre-rHuEPO }}$} & \multirow{2}{*}{$\frac{[\mathrm{Hb}]}{\text { post-rHuEPO }}$} & \multirow{2}{*}{$\frac{\Delta[\mathrm{Hb}}{g \cdot d l^{-1}}$} \\
\hline & & & & liters & \%pred & & & & & & & & & \\
\hline \multicolumn{15}{|c|}{ CRF patients $(n=8)$} \\
\hline VVM & 20 & 173 & 57 & 4.3 & $(98)$ & 85 & 101 & 1.0 & 1.1 & 12 & C 1.4 & 8.5 & 11.8 & 3.3 \\
\hline $\mathrm{JCP}$ & 41 & 170 & 61 & 3.7 & (99) & 84 & 101 & 1.1 & 1.0 & 10.5 & CA 1.6 & 7.8 & 10.7 & 2.9 \\
\hline ESG & 25 & 160 & 54 & 3.7 & (99) & 83 & 112 & 1.3 & 1.2 & 12 & C 1.4 & 7.3 & 11.2 & 3.9 \\
\hline JPF & 21 & 163 & 50 & 3.9 & (99) & 84 & 101 & 1.1 & 1.0 & 10.5 & C 1.2 & 7.6 & 11.8 & 4.2 \\
\hline IEC & 34 & 159 & 59 & 3.5 & (102) & 76 & 99 & 1.2 & 1.1 & 12 & CA 1.4 & 6.6 & 12.1 & 5.5 \\
\hline DGR & 30 & 173 & 62 & 3.8 & $(92)$ & 77 & 97 & 1.1 & 1.1 & 12 & C 1.6 & 8.5 & 13.3 & 4.8 \\
\hline ARC & 22 & 178 & 71 & 5.4 & $(95)$ & 85 & 95 & 1.3 & 1.2 & 12 & C 1.8 & 7.3 & 11.3 & 4.0 \\
\hline EMC & 24 & 170 & 66 & 3.7 & (89) & 87 & 91 & 1.3 & 1.2 & 12 & C 1.6 & 8.6 & 11.1 & 2.5 \\
\hline Mean & 27 & 168 & 60 & 4.0 & $(96)$ & 83 & 100 & 1.2 & 1.1 & 11.6 & & 7.8 & 11.7 & 3.9 \\
\hline $\mathrm{SD}$ & 7 & 6 & 7 & 0.6 & 4 & 4 & 6 & 0.1 & 0.1 & 0.7 & & 1.0 & 0.8 & 0.9 \\
\hline \multicolumn{15}{|c|}{ Control group $(n=8)$} \\
\hline Mean & 26 & 174 & 71 & 4.3 & $(101)$ & 82 & 102 & & & & & 14.1 & & \\
\hline SD & 3 & 5 & 6 & 0.7 & 4 & 3 & 1 & & & & & 1.0 & & \\
\hline
\end{tabular}

Results expressed as mean $\pm \mathrm{SD}$; CRF patients, eight patients with chronic renal failure; Control group, eight healthy sedentary subjects; FEV ${ }_{1}$, forced expiratory volume in the first $\mathrm{s}$ in liters, and as percentage of predicted value within parentheses (23); $\mathrm{FEV}_{1} / \mathrm{FVC}, \mathrm{FEV}_{1}$ to forced vital capacity ratio; $\mathrm{PaO}_{2}, \mathrm{PO}_{2}$ in arterial blood; $\mathrm{Kt} / \mathrm{V}$ (urea), indicates the decrease of $\mathrm{BUN}$ during each dialysis treatment, dimensionless; PCR, protein catabolic rate expressed in $\mathrm{g} \cdot \mathrm{k}^{-1} \cdot \mathrm{d}$; HD, duration of dialysis in $\mathrm{h} \cdot \mathrm{wk}^{-1}$ (three times a wk); Dialyzer, type of membrane of the dialyzer and surface expressed in square meters: C 1.4, Cuprophane $1.4 \mathrm{~m}^{2}$, CA 1.6, Cellulose Acetate $1.6 \mathrm{~m}^{2}$; [Hb] pre-rHuEPO and [Hb] post-rHuEPO, hemoglobin concentration in the pre$\mathrm{rHuEPO}$ and post-rHuEPO studies expressed in $\mathrm{g} \cdot \mathrm{dl}^{-1}$, respectively; $\Delta[\mathrm{Hb}]$, increase in $[\mathrm{Hb}]$ after rHuEPO therapy. 

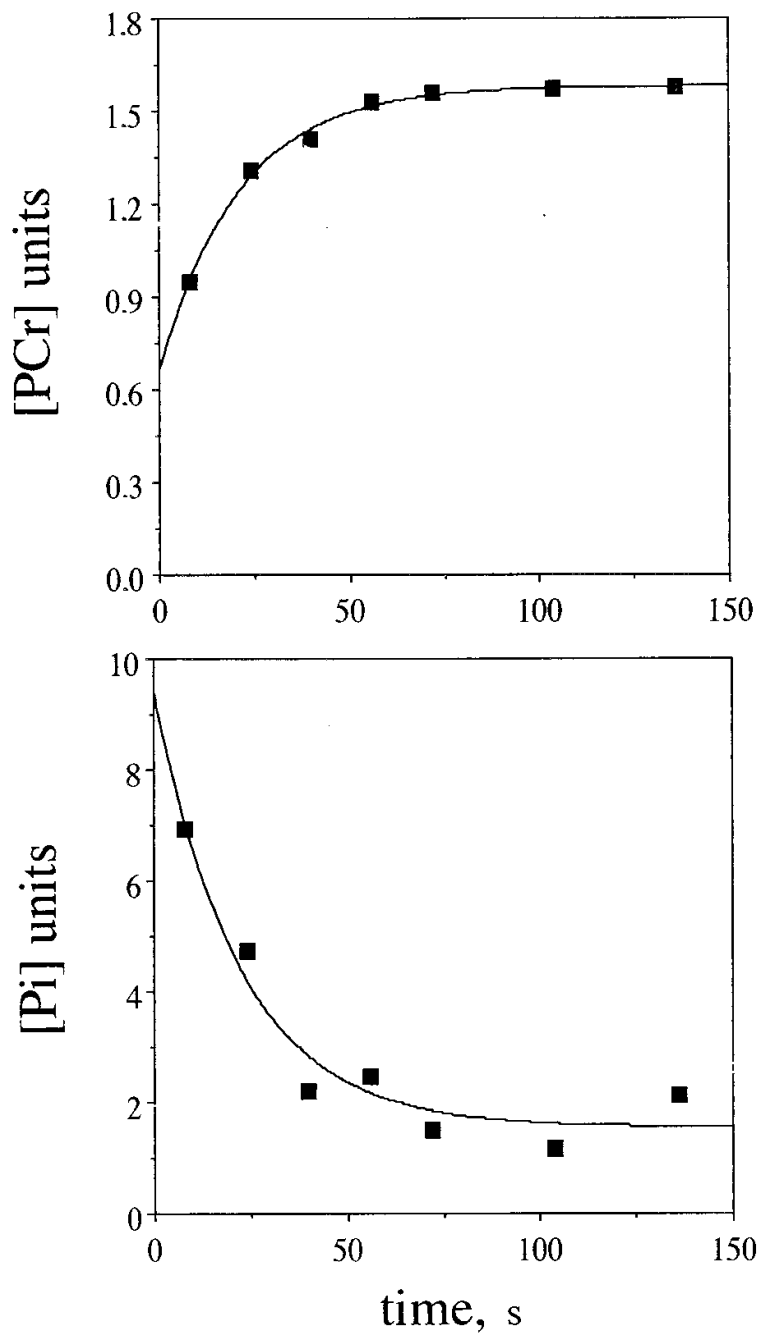

first day, rest and exercise ${ }^{31} \mathrm{P}-\mathrm{MRS}$ were obtained without catheters. On the second day, the subject followed the identical exercise protocol (in time and load) outside the magnet with three catheters in place to obtain $\mathrm{O}_{2}$ transport data. One of the catheters was placed in the radial artery of the contralateral side to the arterio-venous fistula to measure $\mathrm{PO}_{2}, \mathrm{PCO}_{2}, \mathrm{pH}, \mathrm{SaO}_{2}$, lactate, and [Hb] in arterial blood. In the femoral venous vein of the left leg, a 7-F catheter was advanced $7 \mathrm{~cm}$ into the vessel with the tip distally oriented (16), and a $2.5-\mathrm{F}$ thermistor was advanced $5 \mathrm{~cm}$ proximally. Measurements of femoral venous blood flow by short term steady state thermodilution principle and measurements of the above variables in arterial and femoral venous blood were obtained. All patients were strongly encouraged to maintain the same level of daily physical activity between the preand post-rHuEPO studies despite any improvement in their quality of life. The time elapsed between pre- and post-rHuEPO studies was $4.2 \pm 1 \mathrm{mo}$.

${ }^{31} P$-MRS measurements. Studies were carried out using a $1.5 \mathrm{~T}$ General Electric Signa Advantage System (General Electric, Milwaukee, WI) $(160 \times 52 \mathrm{~cm}$ bore $)$ operating at a frequency of 63.65 and $25.86 \mathrm{MHz}$ for the hydrogen-1 and the phosphorus-31 nucleus, respectively, connected to a Spectroscopy Analysis Workstation SUN 3/470 (Sun Microsystems Inc., Mountain View, CA). Subjects were placed in the magnet in a supine position, head first, and the elliptical distributed capacitance surface coil $(14.5 \times 6.5 \mathrm{~cm})$, pretuned at the phosphorus resonant frequency, was positioned and fixed over the vastus medialis muscle of the left leg. Then, the MVC was determined and the position of the surface coil was checked with spin-echo T1weighted images as described in detail in reference 24. Phosphorus-31

Figure 1. Plots of [PCr] and [Pi] (y-axis) over time, expressed in $\mathrm{s}$ $(x$-axis). Filled squares correspond to serial measurements carried out immediately after an exercise step in a representative patient. Continuous lines represent the monoexponential fitting to measured data points used to estimate $[\mathrm{PCr}]$ and $[\mathrm{Pi}]$ extrapolated at time zero after exercise $\left(\left[\mathrm{PCR}_{\mathrm{t} 0}\right]\right.$ and $\left[\mathrm{Pi}_{\mathrm{t} 0}\right]$, respectively). See Methods for additional explanations.
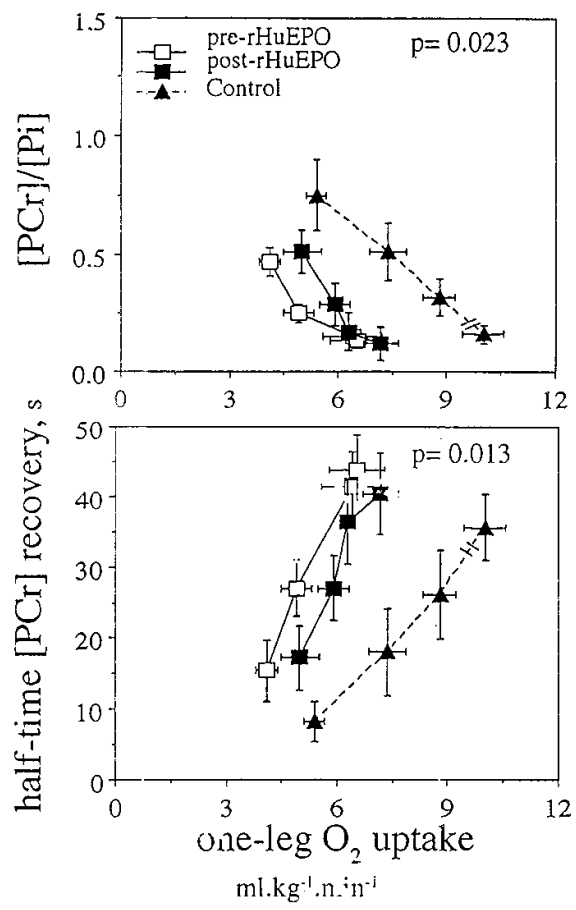
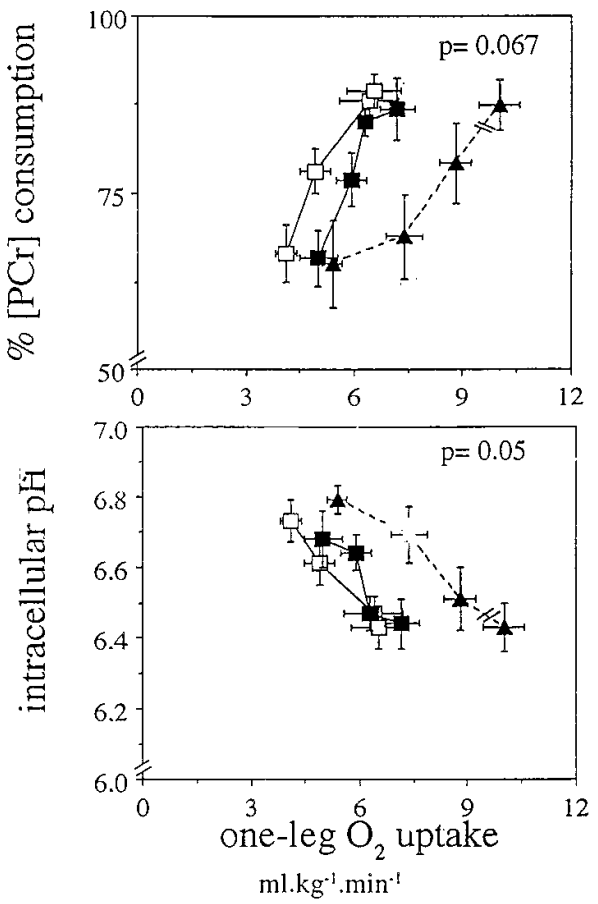

Figure 2. Plots of the ${ }^{31} \mathrm{P}-\mathrm{MRS}$ variables ( $y$-axis) measured during submaximal and peak exercise as a function of one-leg $\mathrm{O}_{2}$ uptake expressed in $\mathrm{ml} \times \mathrm{kg}^{-1} \times \mathrm{min}^{-1}$ ( $\mathrm{x}$-axis). $[\mathrm{PCr}] /[\mathrm{Pi}]$, phosphocreatine to inorganic phosphate ratio at time 0 after each workload; \% $[\mathrm{PCr}]$ consumption, percentage of $[\mathrm{PCr}]$ consumed during each workload compared to the measurements done immediately before commencing the exercise at each workload; half-time of [PCr] recovery during the resting period after each work load, expressed in s; and, intracellular $\mathrm{pH}$, intracellular $\mathrm{pH}$ at $8 \mathrm{~s}$ after each exercise period. In each panel, the three initial workloads correspond to measurements done at 20, 25, and $30 \%$ of MVC, which were carried out in all the subjects studied. The highest workload corresponds to the measurements done at peak exercise. Results are expressed as mean \pm SEM. 

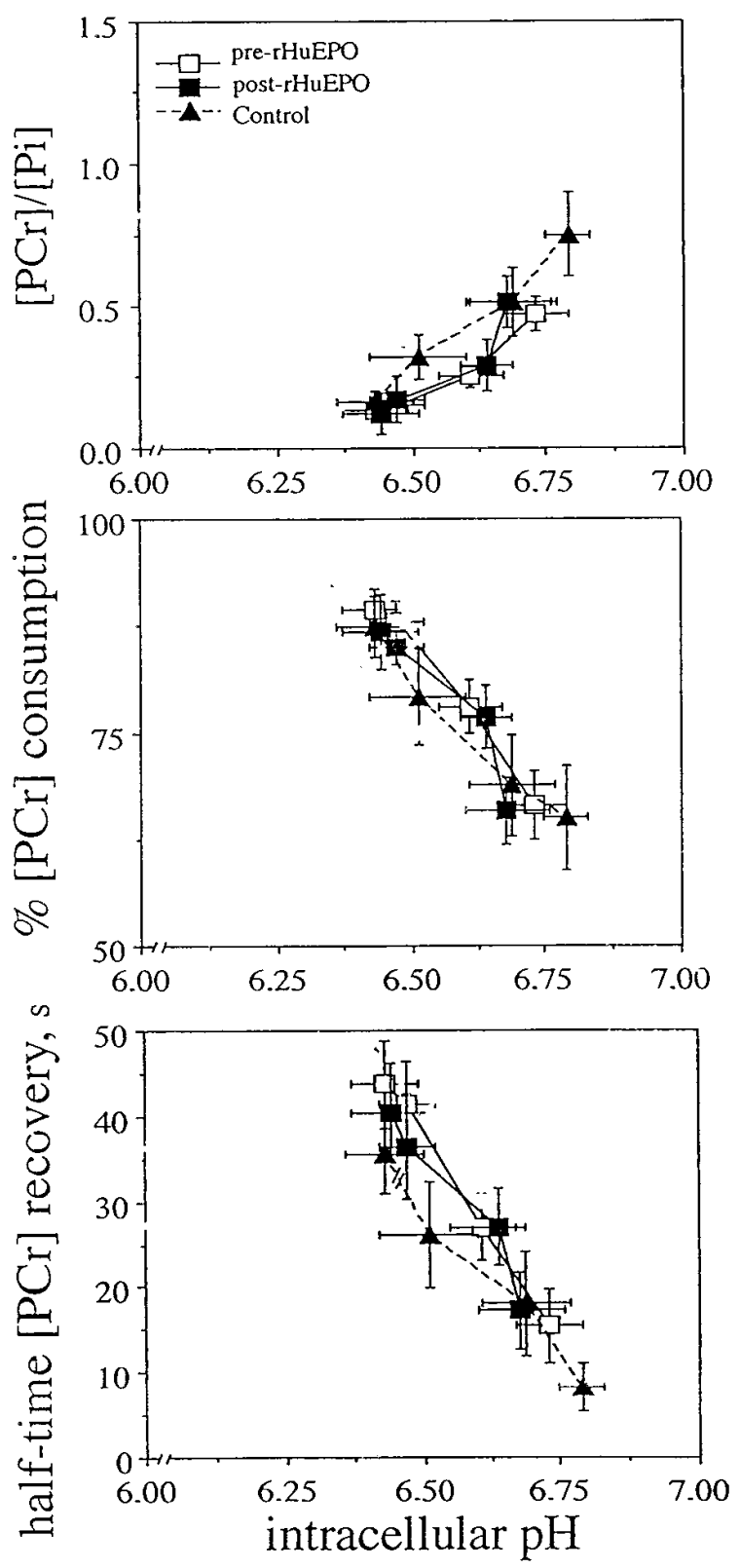

Figure 3. $[\mathrm{PCr}] /[\mathrm{Pi}]$ ratio, \%[PCr] consumption, and half-time of [PCr] recovery, expressed in s, ( $y$-axis) as a function of intracellular $\mathrm{pH}$ ( $x$-axis). Results are expressed as mean \pm SEM. See text for additional explanations.

spectra were obtained using $180^{\circ}$ pulses as measured at the center of the coil. A total of 1,024 data points were collected over a spectral width of 2,500 Hz.

Measurements at rest. Four dummy scans plus 128 transients were accumulated for each spectrum with a recycling time of $2 \mathrm{~s}$. Before Fourier transform, a zero filling to 2,048 data points and apodization by exponential multiplication of $3 \mathrm{~Hz}$ were applied to the free induction decay. Spectra were manually phased and baseline was corrected using a c-spline function.

Measurements during exercise. After four initial dummy scans, spectra of 8 transients with a repetition time of $2 \mathrm{~s}$ (resolution time of $16 \mathrm{~s}$ ) were continuously recorded being the first spectrum obtained at rest before starting the exercise. Before Fourier transform, manual phase and baseline correction, a zero filling to 2,048 data points and apodization by exponential multiplication of $5 \mathrm{~Hz}$ were applied to the free induction decay. For all spectra, the area under each resonance and its chemical shift were obtained after adjusting to pure lorentzian lines by the Marquardt-Levenberg fitting routine. The spectra collected in the resting period between successive workloads were used for analysis, but those collected during the 2 min exercise could not be analyzed because of the movements of the legs. The collection of a new set of spectra was initiated just after the end of the exercise at each workload. The phosphocreatine ([PCr] $)$ and the inorganic phosphate $([\mathrm{Pi}])$ concentrations were therefore extrapolated to time 0 after cessation of exercise at each workload $\left(\left[\mathrm{PCr}_{\mathrm{t} 0}\right]\right.$ and $\left[\mathrm{Pi}_{\mathrm{t} 0}\right]$, respectively) by fitting the resonance area values to monoexponential functions with the Enzfitter version 1.03 software package (ElsevierBiosoft, Cambridge, UK) (Fig. 1). The $\left[\mathrm{PCr}_{\mathrm{t} 0}\right]$ and $\left[\mathrm{Pi}_{\mathrm{t} 0}\right]$ were used to calculate the $[\mathrm{PCr}] /[\mathrm{Pi}]$ ratio, the $\%[\mathrm{PCr}]$ consumption at each workload ( $\%[\mathrm{PCr}]$ consumption), and the individual half-time recovery of phosphocreatine after each exercise step. The intracellular $\mathrm{pH}(\mathrm{pHi})$ was calculated using the formula: $\mathrm{pHi}=6.75+\log [(d-3.27) /$ $(5.69-d)$ ], where $d$ is the chemical shift distance in ppm between the $\mathrm{Pi}$ and the PCr resonances (25). Both the pHi calculated from the first spectrum $(8 \mathrm{~s})$ after cessation of exercise and that corresponding to the nadir during the recovery period were analyzed.

$\mathrm{O}_{2}$ transport measurements. Subject preparation, safety precautions, and technical aspects of the measurement of femoral venous blood gases and blood flow have been described in detail previously $(10,16,26)$. On-line calculations of whole-body $\mathrm{O}_{2}$ uptake $\left(\mathrm{VO}_{2}\right)$, $\mathrm{CO}_{2}$ output, minute ventilation, respiratory exchange ratio, heart rate, and respiratory rate were averaged sequentially over $15 \mathrm{~s}$ intervals and then displayed on a screen monitor to observe the progress of the tests. In each test, measurements were made at rest and during the second min at each workload. In each instance the following measurements were made: (a) $\mathrm{PO}_{2}, \mathrm{PCO}_{2}$, pH (IL model 1302, pH/Blood gas analyzer and tonometer model 237; Instrumentation Laboratories, Milan, Italy), oxyhemoglobin saturation, hemoglobin concentration ([Hb]) (IL 482 co-oximeter), and blood lactate concentrations (YSI 23L blood lactate analyzer; Yellow Springs Instruments, Yellow Springs, $\mathrm{OH}$ ) from simultaneous arterial and femoral venous blood samples; and (b) femoral venous blood flow ( Q leg) by thermodilution and arterial pressure. Calculations of the variables have been previously reported in detail in reference 10 .

Data analysis. Results are expressed as mean \pm SD. After $\mathrm{rHuEPO}$, changes in Qleg were compared using an analysis of covariance after demonstrating existence of a linear relationship between Q leg and whole-body $\mathrm{VO}_{2}$ (as work rate was increased) with no variations in the slope from pre- to post-rHuEPO. Comparisons between pre- and post-rHuEPO studies were done using Student paired $t$ test, and those between post-rHuEPO and the control group of healthy sedentary subjects were carried out using Student unpaired $t$ test. Unless otherwise stated, comparisons of submaximal exercise were done using pooled data. Statistical significance was set at $P \leq 0.05$.

\section{Results}

Anthropometric data, age, lung function, and changes in $[\mathrm{Hb}]$ in the eight CRF patients and the corresponding data from the eight controls are indicated in Table I. After rHuEPO, [Hb] increased by $3.9 \pm 0.9 \mathrm{~g} \times \mathrm{dl}^{-1}(50 \%)$, from $7.8 \pm 1.0$ to $11.7 \pm$ $0.8 \mathrm{~g} \times \mathrm{dl}^{-1}(P=0.0001)$.

Effects of rHuEPO therapy on cellular bioenergetics. Erythropoietin therapy did not affect the phosphocreatine to inorganic phosphate ratio $([\mathrm{PCr}] /[\mathrm{Pi}])$ either at rest $(8.9 \pm 1.2$ vs. $8.8 \pm 1.2$, pre- and post-rHuEPO, respectively) or, at a given $\dot{\mathrm{V}} \mathrm{O}_{2}$ leg, during exercise (Fig. 2). Likewise, during submaximal and peak exercise, no significant changes in (a) $[\mathrm{PCr}]$ consumption expressed as percentage of the [PCr] measured immediately before each work load (\%[PCr] consumption); $(b)$ intracellular $\mathrm{pH}(\mathrm{pHi})$; nor in (c) half-time of $[\mathrm{PCr}]$ recovery 


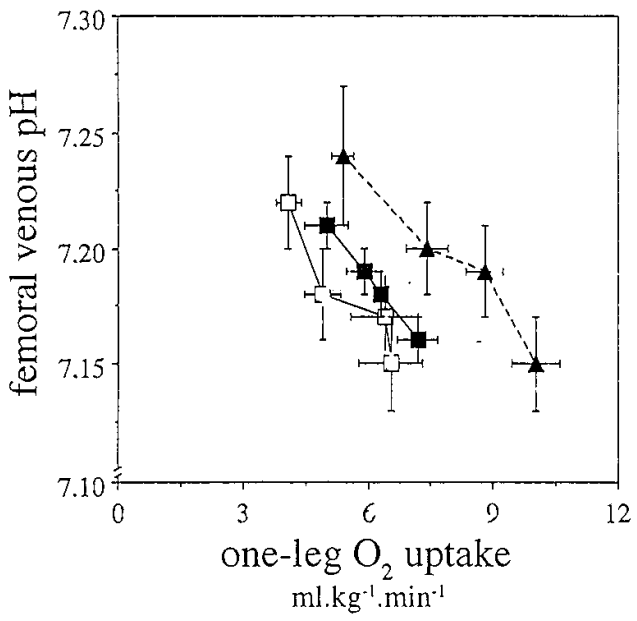

ml.kg-1. min $^{-1}$

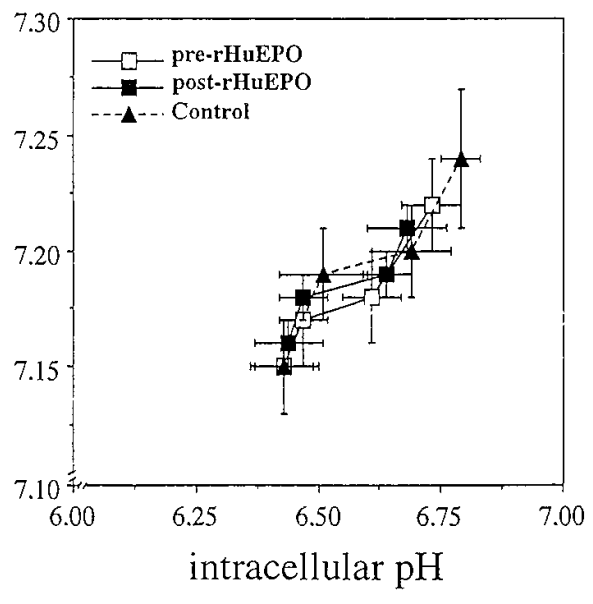

Figure 4. Left: Femoral venous $\mathrm{pH}$ ( $y$-axis) as a function of oneleg $\mathrm{O}_{2}$ uptake expressed in $\mathrm{ml} \times$ $\mathrm{kg} \times \min ^{-1}$ ( $x$-axis). Right: Relationships between femoral venous $\mathrm{pH}$ ( $y$-axis) and intracellular $\mathrm{pH}$ ( $x$-axis) in the three groups. See text for additional explanations.

Table II. $\mathrm{O}_{2}$ Transport Variables during Submaximal and Peak Exercise $(n=8)$

\begin{tabular}{|c|c|c|c|c|c|c|c|c|}
\hline & & Rest & $20 \% \mathrm{MVC}$ & $25 \% \mathrm{MVC}$ & $30 \% \mathrm{MVC}$ & $\begin{array}{c}\text { Peak } \\
\text { exercise }\end{array}$ & $\begin{array}{c}\mathrm{P} \\
\text { pre-post }\end{array}$ & $\begin{array}{c}\mathrm{P} \\
\text { post-con }\end{array}$ \\
\hline \multirow{3}{*}{$\begin{array}{l}\mathrm{PfvO}_{2} \\
\mathrm{mmHg}\end{array}$} & Pre-rHuEPO & $32.2 \pm 8.8$ & $22.2 \pm 2.0$ & $22.1 \pm 3.3$ & $20.1 \pm 3.1$ & $20.2 \pm 3.0$ & \multirow[t]{3}{*}{0.01} & \multirow[t]{3}{*}{ NS } \\
\hline & Post-rHuEPO & $44.3 \pm 13.9$ & $26.2 \pm 6.2$ & $25.5 \pm 4.2$ & $24.7 \pm 4.6$ & $25.9 \pm 5.6$ & & \\
\hline & Control & $43.8 \pm 11.9$ & $24.3 \pm 4.2$ & $23.0 \pm 2.7$ & $21.6 \pm 2.1$ & $21.8 \pm 3.1$ & & \\
\hline \multirow{3}{*}{$\begin{array}{l}\mathrm{PfvCO}_{2} \\
\mathrm{mmHg}\end{array}$} & Pre-rHuEPO & $39.0 \pm 3.3$ & $59.7 \pm 6.6$ & $57.3 \pm 5.3$ & $53.7 \pm 7.3$ & $53.3 \pm 7.2$ & \multirow[t]{3}{*}{ NS } & \multirow[t]{3}{*}{0.02} \\
\hline & Post-rHuEPO & $36.9 \pm 4.0$ & $58.1 \pm 6.8$ & $54.3 \pm 4.3$ & $52.9 \pm 8.0$ & $53.2 \pm 6.9$ & & \\
\hline & Control & $40.2 \pm 3.4$ & $64.1 \pm 10.3$ & $63.7 \pm 7.3$ & $62.3 \pm 5.7$ & $62.0 \pm 6.9$ & & \\
\hline \multirow[t]{3}{*}{$\mathrm{pH}_{\mathrm{fv}}$} & Pre-rHuEPO & $7.39 \pm 0.02$ & $7.20 \pm 0.05$ & $7.18 \pm 0.06$ & $7.17 \pm 0.05$ & $7.15 \pm 0.05$ & \multirow[t]{3}{*}{ NS } & \multirow[t]{3}{*}{ NS } \\
\hline & Post-rHuEPO & $7.38 \pm 0.03$ & $7.21 \pm 0.04$ & $7.19 \pm 0.04$ & $7.18 \pm 0.04$ & $7.16 \pm 0.04$ & & \\
\hline & Control & $7.42 \pm 0.04$ & $7.24 \pm 0.08$ & $7.20 \pm 0.07$ & $7.19 \pm 0.06$ & $7.15 \pm 0.06$ & & \\
\hline \multirow{3}{*}{$\begin{array}{l}\mathrm{CaO}_{2} \\
\mathrm{~m} \cdot 100 \mathrm{ml}^{-1}\end{array}$} & Pre-rHuEPO & $10.7 \pm 0.9$ & $10.8 \pm 0.9$ & $10.8 \pm 0.8$ & $10.9 \pm 0.9$ & $10.9 \pm 0.8$ & \multirow[t]{3}{*}{0.001} & \multirow[t]{3}{*}{0.001} \\
\hline & Post-rHuEPO & $15.7 \pm 1.0$ & $15.8 \pm 0.9$ & $16.1 \pm 1.1$ & $16.3 \pm 1.1$ & $16.3 \pm 1.2$ & & \\
\hline & Control & $19.2 \pm 1.4$ & $19.6 \pm 1.5$ & $19.7 \pm 1.9$ & $19.7 \pm 2.0$ & $19.9 \pm 1.8$ & & \\
\hline \multirow{3}{*}{$\begin{array}{l}\mathrm{CfvO}_{2} \\
\mathrm{~m} \cdot 100 \mathrm{ml}^{-1}\end{array}$} & Pre-rHuEPO & $6.9 \pm 0.5$ & $3.7 \pm 0.3$ & $3.3 \pm 0.2$ & $2.9 \pm 0.1$ & $2.9 \pm 0.1$ & \multirow[t]{3}{*}{0.001} & \multirow[t]{3}{*}{0.001} \\
\hline & Post-rHuEPO & $12.3 \pm 0.9$ & $5.8 \pm 0.4$ & $5.5 \pm 0.3$ & $5.3 \pm 1.0$ & $5.2 \pm 0.4$ & & \\
\hline & Control & $15.7 \pm 1.0$ & $6.6 \pm 0.7$ & $5.8 \pm 0.5$ & $5.1 \pm 0.4$ & $4.8 \pm 0.4$ & & \\
\hline \multirow{3}{*}{$\begin{array}{l}\text { Q }{ }_{\text {leg }} \\
\text { liter.min }\end{array}$} & Pre-rHuEPO & - & $3.4 \pm 0.6$ & $3.9 \pm 0.8$ & $4.9 \pm 1.5$ & $4.9 \pm 1.5$ & \multirow[t]{3}{*}{0.04} & \multirow[t]{3}{*}{ NS } \\
\hline & Post-rHuEPO & - & $3.0 \pm 0.9$ & $3.3 \pm 0.6$ & $3.6 \pm 0.8$ & $3.9 \pm 1.0$ & & \\
\hline & Control & - & $3.0 \pm 0.4$ & $3.8 \pm 0.6$ & $4.4 \pm 0.5$ & $4.7 \pm 0.8$ & & \\
\hline \multirow{3}{*}{$\begin{array}{l}\dot{\mathrm{Q}} \mathrm{O}_{2 \mathrm{leg}} \\
\text { liter.min }^{-1}\end{array}$} & Pre-rHuEPO & - & $0.37 \pm 0.09$ & $0.43 \pm 0.10$ & $0.52 \pm 0.20$ & $0.54 \pm 0.19$ & \multirow[t]{3}{*}{ NS } & \multirow[t]{3}{*}{0.001} \\
\hline & Post-rHuEPO & - & $0.47 \pm 0.13$ & $0.53 \pm 0.08$ & $0.57 \pm 0.10$ & $0.63 \pm 0.13$ & & \\
\hline & Control & - & $0.59 \pm 0.10$ & $0.75 \pm 0.15$ & $0.86 \pm 0.16$ & $0.94 \pm 0.16$ & & \\
\hline \multirow{3}{*}{$\begin{array}{l}\mathrm{O}_{2} \mathrm{ER} \\
\%\end{array}$} & Pre-rHuEPO & $35 \pm 14.8$ & $66 \pm 7.6$ & $69 \pm 5.3$ & $73 \pm 4.1$ & $73 \pm 4.0$ & \multirow[t]{3}{*}{0.03} & \multirow[t]{3}{*}{0.05} \\
\hline & Post-rHuEPO & $22 \pm 18.2$ & $63 \pm 6.9$ & $65 \pm 6.9$ & $67 \pm 7.9$ & $68 \pm 8.2$ & & \\
\hline & Control & $18 \pm 14.5$ & $67 \pm 8.5$ & $70 \pm 7.1$ & $74 \pm 5.3$ & $76 \pm 6.1$ & & \\
\hline \multirow{3}{*}{$\begin{array}{l}\dot{\mathrm{V}} \mathrm{O}_{2 \mathrm{leg}} \\
\text { liter.min }\end{array}$} & Pre-rHuEPO & - & $0.25 \pm 0.07$ & $0.29 \pm 0.07$ & $0.40 \pm 0.16$ & $0.40 \pm 0.15$ & \multirow[t]{3}{*}{ NS } & \multirow[t]{3}{*}{0.001} \\
\hline & Post-rHuEPO & - & $0.29 \pm 0.07$ & $0.34 \pm 0.05$ & $0.38 \pm 0.05$ & $0.43 \pm 0.09$ & & \\
\hline & Control & - & $0.39 \pm 0.07$ & $0.53 \pm 0.12$ & $0.64 \pm 0.11$ & $0.71 \pm 0.13$ & & \\
\hline
\end{tabular}

Results expressed as mean $\pm \mathrm{SD} ; 20,25$ and 30\% MVC, correspond to the submaximal workloads carried out in all the subjects (actual values of each of these workloads expressed in watts are indicated in Table III); peak exercise, measurements obtained at exhaustion; Pre-rHuEPO, Post-rHuEPO, and Control, results before $\mathrm{rHuEPO}$ therapy, post-rHuEPOtherapy, and from the sedentary control subjects respectively; $\mathrm{PfvO}_{2}, \mathrm{PfvCO}_{2}$, and $\mathrm{pH}_{\mathrm{fv}}$, femoral venous $\mathrm{PO}_{2}, \mathrm{PCO}_{2}$, and $\mathrm{pH}$, respectively; $\mathrm{CaO}_{2}, \mathrm{CafvO}_{2}, \mathrm{O}_{2}$ content in arterial and femoral venous blood, respectively; $\mathrm{Q}_{\text {leg }}$, femoral venous blood flow; $\dot{\mathrm{Q}} \mathrm{O}_{2 \text { leg }}$, one-leg $\mathrm{O}_{2}$ delivery; $\mathrm{O}_{2} \mathrm{ER}$, muscle $\mathrm{O}_{2}$ extraction as a percentage; $\dot{\mathrm{V}} \mathrm{O}_{2 \text { leg }}$, one leg $\mathrm{O}_{2}$ uptake; pre-post, probability of the comparisons between pre and post-rHuEPO measurements at peak exercise (paired analysis); post-con, probability of the comparisons between post-rHuEPO study and sedentary control subjects at peak exercise (unpaired analysis). 
after each exercise step, expressed in seconds, were observed after rHuEPO.

Comparison of ${ }^{31} \mathrm{P}-\mathrm{MRS}$ between post-rHuEPO and controls. The $[\mathrm{PCr}] /[\mathrm{Pi}]$ ratio at rest was significantly higher in controls than in the post-rHuEPO group (10.9 \pm 1.5 vs. $8.8 \pm 1.2$, respectively $)(P=0.01)$. As shown in Fig. 2 , at a given $\dot{\mathrm{V}} \mathrm{O}_{2}$ leg, the energetic status of the muscle cells as reflected by $[\mathrm{PCr}] /[\mathrm{Pi}], \%[\mathrm{PCr}]$ consumption and half-time of $[\mathrm{PCr}]$ recovery and the intracellular $\mathrm{pH}$ was significantly higher in controls. For example, at a $\dot{\mathrm{V}} \mathrm{O}_{2} \mathrm{leg}$ of $\sim 6.2 \mathrm{ml} \times \mathrm{kg}^{-1} \times \mathrm{min}^{-1}$, the ${ }^{31} \mathrm{P}-\mathrm{MRS}$ results were (a) $[\mathrm{PCr}] /[\mathrm{Pi}]$ ratio, $0.60 \pm 0.33$ vs. $0.26 \pm 0.13$, control and post-rHuEPO group, respectively) $(P=0.023) ;(b) \%[\mathrm{PCr}]$ consumption, $68 \pm 15.5$ vs. $82 \pm 9.7 \%$ $(P=0.067) ;(c)$ half-time of $[\mathrm{PCr}]$ recovery, $9 \pm 6.8$ vs. $30 \pm 18.7 \mathrm{~s}$ $(P=0.013) ;(d)$ pHi calculated from the first spectrum $(8 \mathrm{~s})$ after cessation of exercise, $6.77 \pm 0.15$ vs. $6.55 \pm 0.23(P=0.05)$; and (e) pHi corresponding to the nadir during the recovery period, $6.68 \pm 0.16$ vs. $6.37 \pm 0.21)$, respectively $(P=0.012)$. However, the differences between post-rHuEPO and control group in $[\mathrm{PCr}] /[\mathrm{Pi}]$ ratio and $\%[\mathrm{PCr}]$ consumption during exercise and in half-time of [PCr] recovery during the interspersed resting periods disappeared when these variables were expressed as a function of $\mathrm{pHi}$. Identical results were obtained either using $\mathrm{pHi}$ calculated from the first spectrum $(8 \mathrm{~s})$ after cessation of exercise (Fig. 3) or that corresponding to the nadir during the recovery period.

Relationships between intracellular $\mathrm{pH}$ and femoral venous $\mathrm{pH}$. No differences in femoral venous $\mathrm{pH}\left(\mathrm{pH}_{\mathrm{fv}}\right)$, at a given $\dot{\mathrm{V}} \mathrm{O}_{2}$ leg, were observed between pre- and post-rHuEPO studies. As depicted in Fig. 4 (right), intracellular and femoral venous $\mathrm{pH}$ track each other in all three groups.

Effects of $\mathrm{rHuEPO}$ therapy on muscle $\mathrm{O}_{2}$ transport. Arterial $\mathrm{O}_{2}$ content $\left(\mathrm{CaO}_{2}\right)$ increased by $50 \%(P<0.001)$, parallel to the rise observed in [Hb] (Table II). However, femoral venous blood flow (Q̈leg) was consistently lower $(-20 \%)$ at each workload after rHuEPO $(P<0.04)$ (Fig. 5). The reduction in Qleg largely offset the effect of the increase in $\mathrm{CaO}_{2}$ on $\mathrm{O}_{2}$ delivery ( $\dot{\mathrm{QO}}_{2} \mathrm{leg}$ ). At peak exercise, $\dot{\mathrm{QO}}_{2}$ leg did not change significantly after $\mathrm{rHuEPO}$, the mean value increasing by $17 \%$.

We confirmed existence of a low muscle $\mathrm{O}_{2}$ conductance $\left(\mathrm{DO}_{2}\right)$ in CRF patients as previously seen (10), but no increase in $\mathrm{DO}_{2}$ after $\mathrm{rHuEPO}$ was found $(10.9 \pm 4.2$ and $10.9 \pm 2.6 \mathrm{ml}$ $\times \mathrm{mmHg}^{-1} \times \mathrm{min}^{-1}$, pre- and post-rHuEPO, respectively). As indicated in Table II, one-leg $\mathrm{O}_{2}$ extraction ratio $\left(\mathrm{O}_{2} \mathrm{ER}\right)$ decreased after rHuEPO therapy at each workload. At maximum exercise, $\mathrm{O}_{2}$ ER fell from $73 \pm 4.0$ to $68 \pm 8.2 \%(P=0.03)$. Consequently, the $17 \%$ increase in $\mathrm{QO}_{2}$ leg was counterbalanced by the $7 \%$ drop in $\mathrm{O}_{2}$ ER such that both $\dot{\mathrm{V}} \mathrm{O}_{2}$ leg (Table II) and whole-body $\dot{\mathrm{V}} \mathrm{O}_{2}$ (Table III) did not change significantly (only +8 and $+6 \%$, respectively) after rHuEPO therapy.

Comparison of muscle $\mathrm{O}_{2}$ transport at peak exercise between post-rHuEPO and controls. Muscle $\mathrm{O}_{2}$ transport variables at peak exercise expressed as percent of the values obtained in the control subjects are shown in Fig. 6 (mean \pm SEM). Both $[\mathrm{Hb}]$ and $\mathrm{CaO}_{2}$ in the CRF patients postrHuEPO were $\sim 18 \%$ lower than the corresponding values in the control group, whereas peak Qleg was similar (65 \pm 1.1 vs. $67 \pm 1.2 \mathrm{ml} \times \mathrm{kg}^{-1} \times \mathrm{min}^{-1}$, post-rHuEPO and controls respectively). Consequently, $\mathrm{QO}_{2} \mathrm{leg}$ was $\sim 20 \%$ lower in CRF patients post-rHuEPO. As expected from the low muscle $\mathrm{O}_{2}$ conductance in CRF patients, $\mathrm{O}_{2} \mathrm{ER}$ after $\mathrm{rHuEPO}$ was also lower

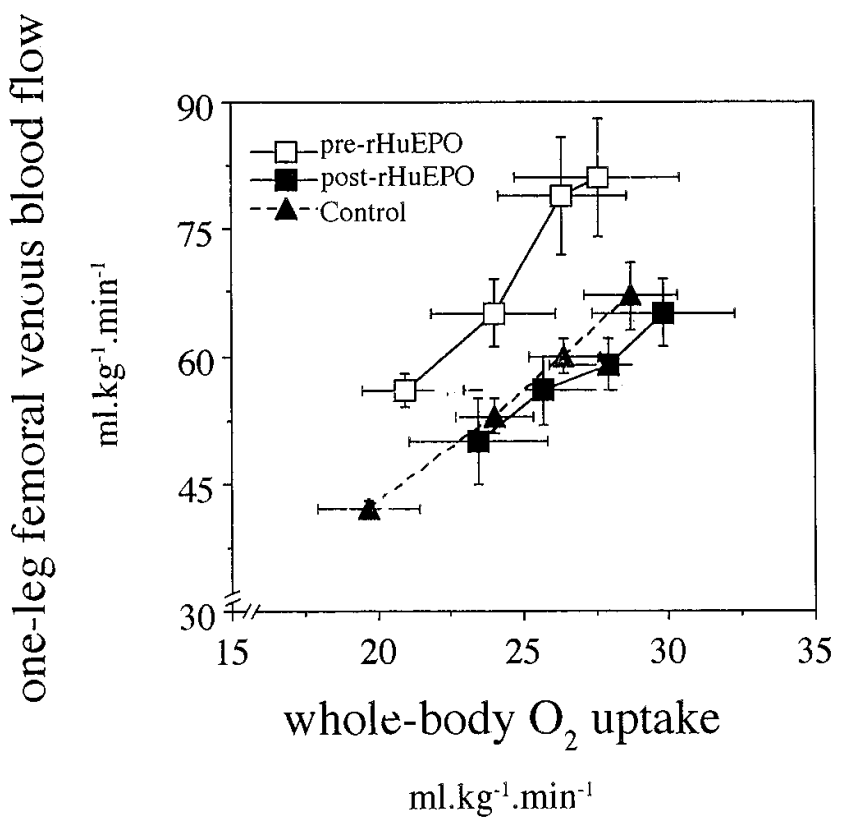

Figure 5. Relationships between femoral venous blood flow (Q்leg), expressed in $\mathrm{ml} \times \mathrm{kg}^{-1} \times \mathrm{min}^{-1}$ (y-axis) and whole-body $\mathrm{O}_{2}$ uptake, expressed in $\mathrm{ml} \times \mathrm{kg}^{-1} \times \min ^{-1}$ ( $x$-axis). At any given $\dot{\mathrm{V}}_{2}$, Q leg significantly decreased after $\mathrm{rHuEPO}$. No differences were detected between the post-rHuEPO and controls. Results are expressed as mean \pm SEM.

than in controls $(68 \pm 8.2$ and $76 \pm 6.1 \%$, respectively) $(P=$ 0.05). The combined effects of $\mathrm{QO}_{2} l e g$ and $\mathrm{O}_{2} \mathrm{ER}$ on $\mathrm{O}_{2}$ uptake explain how peak $\dot{\mathrm{V}} \mathrm{O}_{2}$ leg in CRF patients post-rHuEPO was $28 \%$ lower than that observed in controls $(7.2 \pm 1.4$ and $10.0 \pm 1.6 \mathrm{ml} \times \mathrm{kg}^{-1} \times \mathrm{min}^{-1}$, respectively) $(P=0.002)$.

\section{Discussion}

Main findings. The present study confirms our previous results (10) suggesting that the limited increase of maximum $\mathrm{O}_{2}$ uptake $\left(\dot{\mathrm{VO}}_{2} \mathrm{max}\right)$ in anemic patients with chronic renal failure (CRF) after increasing the [Hb] up to almost normal levels with rHuEPO therapy can be essentially explained by: (a) hemodynamic changes (reduction of leg blood flow) after rHuEPO; and (b) abnormal muscle $\mathrm{O}_{2}$ conductance from microcirculation to mitochondria (10). The structural basis for the reduced muscle $\mathrm{O}_{2}$ conductance in CRF patients is likely to be a poor muscle microcirculatory network and capillary-myofiber dissociation (11-13) due to uremic myopathy. Two main findings come from the present investigation.

First, muscle cell bioenergetics as characterized by ${ }^{31} \mathrm{P}-\mathrm{MRS}$ signals reflecting [PCr], [Pi], and derived indices (at rest, during exercise, and throughout the recovery period after each exercise step) did not show significant changes after rHuEPO therapy. We suggest that in the face of $\mathrm{O}_{2}$ supply limitation of $\dot{\mathrm{V}} \mathrm{O}_{2}$ max (10), the lack of significant changes in convective $\mathrm{O}_{2}$ delivery $\left(\mathrm{QO}_{2} \mathrm{leg}\right.$ ) can explain lack of increase in $\mathrm{O}_{2}$ flow to mitochondria, and consequently how ${ }^{31} \mathrm{P}-\mathrm{MRS}$ data and $\dot{\mathrm{V}} \mathrm{O}_{2} \mathrm{max}$ both did not change with $\mathrm{rHuEPO}$ in the present investigation. Since $\mathrm{O}_{2}$ supply dependency of $\dot{\mathrm{V}} \mathrm{O}_{2} \max$ in CRF patients was demonstrated in the companion study (10); limited mitochondrial oxidative capacity does not appear to explain the lack of increase in $\dot{\mathrm{V}} \mathrm{O}_{2}$ max after rHuEPO therapy, if 
Table III. Whole-body Variables during Submaximal and Peak Exercise $(n=8)$

\begin{tabular}{|c|c|c|c|c|c|c|c|c|}
\hline & & Rest & $20 \% \mathrm{MVC}$ & $25 \%$ MVC & $30 \% \mathrm{MVC}$ & $\begin{array}{c}\text { Peak } \\
\text { exercise }\end{array}$ & $\begin{array}{c}\mathrm{P} \\
\text { pre-post }\end{array}$ & $\begin{array}{c}\mathrm{P} \\
\text { post-con }\end{array}$ \\
\hline Watts & $\begin{array}{c}\text { Pre-rHuEPO } \\
\text { Post-rHuEPO } \\
\text { Control }\end{array}$ & $\begin{array}{l}0 \\
0 \\
0\end{array}$ & $\begin{array}{l}33 \pm 7 \\
33 \pm 7 \\
36 \pm 6\end{array}$ & $\begin{array}{l}42 \pm 10 \\
42 \pm 10 \\
47 \pm 11\end{array}$ & $\begin{array}{l}53 \pm 12 \\
53 \pm 12 \\
58 \pm 16\end{array}$ & $\begin{array}{l}57 \pm 16 \\
55 \pm 17 \\
65 \pm 17\end{array}$ & NS & NS \\
\hline $\begin{array}{l}\dot{\mathrm{V}_{2}} \\
\text { liters } \cdot \min ^{-1}\end{array}$ & $\begin{array}{c}\text { Pre-rHuEPO } \\
\text { Post-rHuEPO } \\
\text { Control }\end{array}$ & $\begin{array}{l}0.25 \pm 0.05 \\
0.28 \pm 0.07 \\
0.27 \pm 0.06\end{array}$ & $\begin{array}{l}1.26 \pm 0.25 \\
1.39 \pm 0.40 \\
1.40 \pm 0.36\end{array}$ & $\begin{array}{l}1.44 \pm 0.34 \\
1.52 \pm 0.45 \\
1.70 \pm 0.23\end{array}$ & $\begin{array}{l}1.64 \pm 0.42 \\
1.65 \pm 0.33 \\
1.90 \pm 0.22\end{array}$ & $\begin{array}{l}1.67 \pm 0.54 \\
1.77 \pm 0.48 \\
2.03 \pm 0.30\end{array}$ & NS & NS \\
\hline $\begin{array}{l}\dot{\mathrm{VO}}{ }_{2} \\
\mathrm{ml} \cdot \mathrm{min}^{-1} \mathrm{~kg}^{-1}\end{array}$ & $\begin{array}{c}\text { Pre-rHuEPO } \\
\text { Post-rHuEPO } \\
\text { Control }\end{array}$ & $\begin{array}{l}4.1 \pm 1.0 \\
4.8 \pm 1.2 \\
3.8 \pm 0.7\end{array}$ & $\begin{array}{l}20.9 \pm 4.2 \\
23.5 \pm 6.7 \\
19.7 \pm 5.0\end{array}$ & $\begin{array}{l}24.0 \pm 6.0 \\
25.7 \pm 7.7 \\
24.0 \pm 3.7\end{array}$ & $\begin{array}{l}26.4 \pm 6.2 \\
27.9 \pm 5.7 \\
26.4 \pm 3.5\end{array}$ & $\begin{array}{l}27.6 \pm 8.0 \\
29.8 \pm 6.9 \\
28.7 \pm 4.6\end{array}$ & NS & NS \\
\hline $\begin{array}{l}\mathrm{HR} \\
\min ^{-1}\end{array}$ & $\begin{array}{c}\text { Pre-rHuEPO } \\
\text { Post-rHuEPO } \\
\text { Control }\end{array}$ & $\begin{array}{l}84 \pm 14 \\
81 \pm 13 \\
76 \pm 12\end{array}$ & $\begin{array}{l}136 \pm 16 \\
134 \pm 20 \\
129 \pm 24\end{array}$ & $\begin{array}{l}151 \pm 20 \\
152 \pm 22 \\
155 \pm 23\end{array}$ & $\begin{array}{l}163 \pm 13 \\
163 \pm 11 \\
164 \pm 20\end{array}$ & $\begin{array}{l}164 \pm 10 \\
168 \pm 10 \\
171 \pm 8\end{array}$ & NS & NS \\
\hline $\begin{array}{l}{[\text { Lact }]_{\mathrm{a}}} \\
\mathrm{mM}\end{array}$ & $\begin{array}{c}\text { Pre-rHuEPO } \\
\text { Post-rHuEPO } \\
\text { Control }\end{array}$ & $\begin{array}{l}0.6 \pm 0.2 \\
0.5 \pm 0.2 \\
0.6 \pm 0.2\end{array}$ & $\begin{array}{l}3.0 \pm 0.7 \\
2.6 \pm 1.4 \\
2.7 \pm 0.6\end{array}$ & $\begin{array}{l}5.7 \pm 1.5 \\
4.2 \pm 1.9 \\
5.2 \pm 1.7\end{array}$ & $\begin{array}{l}7.8 \pm 2.1 \\
5.7 \pm 2.3 \\
6.7 \pm 1.8\end{array}$ & $\begin{array}{l}8.6 \pm 2.7 \\
6.0 \pm 1.9 \\
7.8 \pm 1.1\end{array}$ & 0.01 & 0.04 \\
\hline
\end{tabular}

Results expressed as mean \pm SD; 20, 25 and 30\% MVC, correspond to the submaximal workloads carried out in all the subjects (actual values of each of these workloads expressed in watts are indicated in this table); peak exercise, measurements obtained at exhaustion; Pre-rHuEPO, Post-rHuEPO, and Control, results before rHuEPO therapy, post-rHuEPO therapy, and from the sedentary control subjects respectively; Watts, workload at each exercise step expressed in watts; $\dot{\mathrm{V}} \mathrm{O}_{2}, \mathrm{O}_{2}$ uptake; $\mathrm{HR}$, heart rate; [Lact $]_{\mathrm{a}}$, lactage concentration in arterial blood expressed in mM; pre-post, probability of the comparisons between pre and post-rHuEPO measurements at peak exercise (paired analysis); post-con, probability of the comparisons between post-rHuEPO study and sedentary control subjects at peak exercise (unpaired analysis).

we assume that supply dependency was also the case in the present patient group.

The second major finding was that the ${ }^{31} \mathrm{P}-\mathrm{MRS}$ results (Fig. 2) depict a lower muscle cell bioenergetic status and a lower intracellular $\mathrm{pH}(\mathrm{pHi})$, at a given $\dot{\mathrm{V}} \mathrm{O}_{2} \mathrm{leg}$, in $\mathrm{CRF}$ pa-

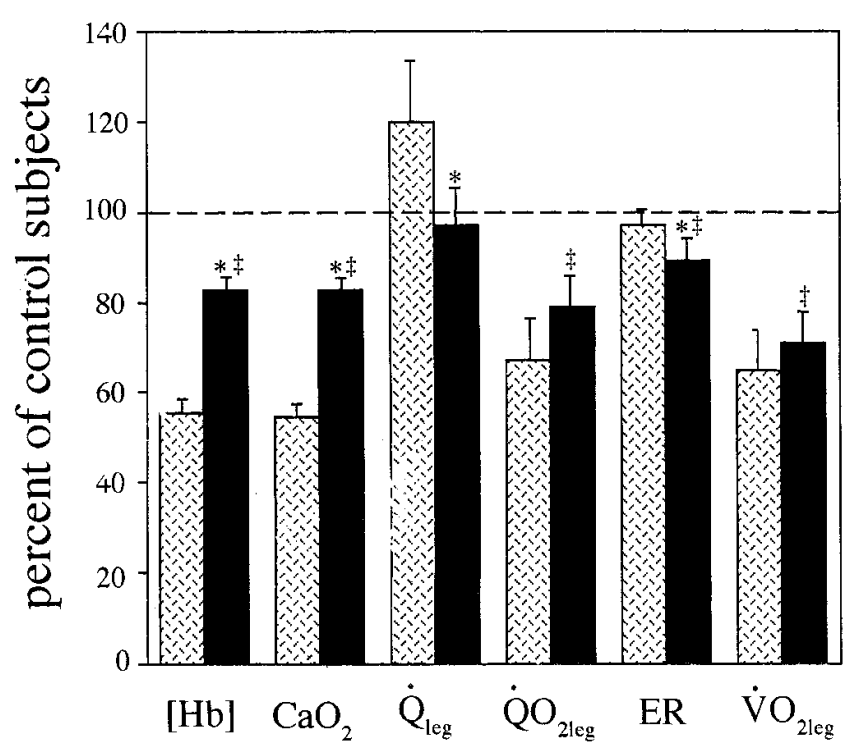

Figure 6. Results of muscle $\mathrm{O}_{2}$ transport variables expressed as percent of the values obtained in the sedentary control subjects. Q leg, $\dot{\mathrm{Q}}_{2} \mathrm{leg}$, and $\dot{\mathrm{V}}_{2} \mathrm{leg}$ have been corrected by body weight. Values are expressed as mean \pm SEM. $* P<0.05$ between pre- and post-rHuEPO (Student's paired $t$-test); $\$ P<0.05$ between post-rHuEPO and controls (Student's unpaired $t$-test). tients post-rHuEPO compared to controls. The longer halftime of [PCr] recovery in CRF patients would suggest reduced mitochondrial function, but because of the complexity of the processes regulating oxidative phosphorylation in the mammalian cell (26), the identification of the precise mechanism(s) responsible for the observed differences between CRF patients and controls is beyond the scope of the present study. However, it should be pointed out that the differences in $[\mathrm{PCr}]$ breakdown and in half-time of [PCr] recovery between $\mathrm{CRF}$ patients post-rHuEPO and control disappeared when these variables $([\mathrm{PCr}] /[\mathrm{Pi}]$ ratio, $\%[\mathrm{PCr}]$ consumption and half-time [PCr] recovery) are expressed as a function of pHi (Fig. 3). Increase in half-time of [PCr] recovery related with low pHi values, but not due to changes in muscle $\mathrm{O}_{2}$ supply, has been reported by McCully et al. (28). Low pHi values increase the half-time of $[\mathrm{PCr}]$ recovery as a result of the effect of $\left[\mathrm{H}^{+}\right]$on the creatine kinase reaction such that $\mathrm{PCr}$ levels no longer strictly depend on changes in ADP concentration. Low $\mathrm{pHi}$ can also inhibit adenosinetriphosphatase rates and lower oxidative capacity (29). The behavior of these energetic indices as a function of pHi suggests that the ${ }^{31} \mathrm{P}-\mathrm{MRS}$ abnormalities may be primarily due to $\left[\mathrm{H}^{+}\right]$-related cytosolic effects on the regulation of the processes involved in $[\mathrm{PCr}]$ breakdown and resynthesis rather than to a primary disturbance of the mitochondrial oxidative capacity $(30,31)$. The marked differences in pHi between patients and controls, at a given $\dot{\mathrm{V}} \mathrm{O}_{2}$ leg, may be in larger part explained by different lactate levels (Table III), although without intracellular lactate concentrations this is somewhat speculative. The slightly lower [Hb] (Table I) observed in post-rHuEPO patients compared with controls does not perturb the interpretation of the differences in cellular bioenergetics. 
Structural and histochemical findings in skeletal muscle biopsies obtained in CRF patents (11-13) indicate poor capillary network and capillary-myofiber dissociation as the foremost characteristic findings, but also myopathic changes that could decrease oxygen-dependent metabolism. Abnormal oxidative capacity is claimed to exist in CRF patients by some authors (19). Diesel et al. (13) also argued for a reduced muscle oxidative capacity in CRF patients but these authors used an inadequate control group consisting of trained athletes rather than sedentary subjects. In contrast, Moore et al. (18) suggest preserved intrinsic oxidative mitochondrial capacity in dialysis patients as compared to transplant recipients and healthy subjects, based on their similar post-exercise recovery of [PCr]/ [Pi] ratio and $\mathrm{pHi}$ to baseline energy status. The present study provides two new insights compared to the work done by Moore et al. (18). First, we examine the effects of a marked increase in $[\mathrm{Hb}]$ after rHuEPO therapy (by 50\%) on muscle bioenergetics. Second, in the present study interpretation of energetic status of the cell (both in the comparison between pre- and post-rHuEPO therapy and in the analysis of the differences between CRF patients post-rHuEPO and healthy sedentary controls) was done, for the first time, using actual muscle $\mathrm{O}_{2}$ transport and $\mathrm{O}_{2}$ uptake data obtained while the subject was performing identical exercise protocol and using the same ergometer. Hence, unnecessary assumptions and uncertainties such as the nature of static and dynamic hand-grip exercise (18) can be avoided.

Differences in $\mathrm{O}_{2}$ transport response to $\mathrm{rHuEPO}$ between the present study and reference 10 . Despite the marked increase in $[\mathrm{Hb}]$ in both investigations (50 and $69 \%$, present study and reference 10, respectively), the weak $\mathrm{O}_{2}$ transport response after $\mathrm{rHuEPO}$ in the present protocol was indeed more evident. The fall in Qleg after rHuEPO was slightly greater than that seen in reference 10 , and at variance with the previous study, muscle oxygen extraction ratio $\left(\mathrm{O}_{2} \mathrm{ER}\right)$ significantly decreased after $\mathrm{rHuEPO}$. These two phenomena can account for the lack of change in one-leg $\mathrm{O}_{2}$ uptake at peak exercise after rHuEPO. A similar lack of response to the rHuEPO therapy was also found in whole-body $\mathrm{O}_{2}$ uptake at peak exercise which, as indicated in Methods, is a fully independent measurement from one-leg $\dot{\mathrm{V}} \mathrm{O}_{2}\left(\dot{\mathrm{V}} \mathrm{O}_{2} \mathrm{leg}\right)$. Since all measurements were done while subjects were breathing room air only, $\mathrm{DO}_{2}$ in this study is analyzed subject to the assumption of $\mathrm{O}_{2}$ supply dependency which was demonstrated in reference 10 . The technical requirements to estimate muscle $\mathrm{O}_{2}$ conductance have been analyzed in detail elsewhere $(10,16,32-35)$. However, it is of note that post-rHuEPO $\mathrm{DO}_{2}$ in these patients $\left(10.9 \pm 1.6 \mathrm{ml} \times \mathrm{mmHg}^{-1} \times \mathrm{min}^{-1}\right)$ was $\sim 60 \%$ of that obtained in controls $\left(18.2 \pm 3.5 \mathrm{ml} \times \mathrm{mmHg}^{-1} \times \mathrm{min}^{-1}\right)$. As suggested by Piiper et al. (14) and shown elsewhere $(10,16)$, the observed reduction of the $\mathrm{O}_{2} \mathrm{ER}$ after $\mathrm{rHuEPO}$ from $73 \pm 4.0$ to $68 \pm 8.2 \%(P<0.03)$ necessarily requires a decrease in diffusional to perfusional conductance ratio $\left(\mathrm{DO}_{2} / \beta \times \dot{\text { Qleg }}\right)$ after $\mathrm{rHuEPO}$. The term $\beta$ corresponds to the slope of the $\mathrm{O}_{2}$ dissociation curve and is the ratio of the arterial to femoral venous $\mathrm{O}_{2}$ content difference and the arterial to femoral venous $\mathrm{PO}_{2}$ difference $\left[\beta=\left(\mathrm{C}_{\mathrm{a}} \mathrm{O}_{2}-\mathrm{C}_{\mathrm{fv}} \mathrm{O}_{2}\right) /\left(\mathrm{P}_{\mathrm{a}} \mathrm{O}_{2}-\mathrm{P}_{\mathrm{fv}} \mathrm{O}_{2}\right)\right]$.

The above described differences in muscle $\mathrm{O}_{2}$ transport between these two investigations (present study and 10), as well as the lack of change in $\mathrm{DO}_{2}$ after rHuEPO in the present study, can be ascribed to the combined effects of two factors: (a) the smaller increase in [Hb] after rHuEPO in this study compared to reference 10 (50 vs. 69\%, respectively); and (b) the larger reduction in peak Qleg after $\mathrm{rHuEPO}$ in the present investigation (by $-20 \%$, from 82 to $65 \mathrm{ml} \times \mathrm{kg}^{-1} \times \mathrm{min}^{-1}$ ) compared to that observed in reference 10 (by $-13 \%$, from 84 to $73 \mathrm{ml} \times \mathrm{kg}^{-1} \times \mathrm{min}^{-1}$ ). The two groups of CRF patients showed a similar exercise performance (relationships between $\dot{\mathrm{V}} \mathrm{O}_{2}$ and work rate and peak $\dot{\mathrm{V}} \mathrm{O}_{2}$ ), evaluated using a regular cycloergometer (post-rHuEPO whole-body $\dot{\mathrm{V}} \mathrm{O}_{2}$ max, 30.6 \pm 6.6 and $33.1 \pm 4.7 \mathrm{ml} \times \mathrm{kg}^{-1} \times \mathrm{min}^{-1}$, present study and reference 10 , respectively). The present study and reference 10 were performed at the same time using identical inclusion criteria.

${ }^{31} P-M R S$ data at rest. Differences of resting $[\mathrm{PCr}] /[\mathrm{Pi}] \mathrm{ra}-$ tios have been reported among normal sedentary subjects, sprinters, and long-distance runners (36), likely reflecting different bioenergetic status associated with differences in muscle fiber-type composition. However, a low [PCr]/[Pi] ratio at rest is a characteristic feature of several different metabolic myopathies $(37,38)$. In the present study, pre-rHuEPO results were below $(P=0.01)$ those seen in the control group with no significant changes after rHuEPO, indicating a lower muscle energetic status in CRF patients (pre- and post-rHuEPO). We suggest this is probably due to uremic myopathy, rather than related to an abnormal $\mathrm{O}_{2}$ supply to mitochondria which, at rest, can be assumed largely above cellular $\mathrm{O}_{2}$ demand. Lower $[\mathrm{PCr}] /[\mathrm{Pi}]$ ratios in $\mathrm{CRF}$ patients compared to their controls $(\mathrm{P}<$ 0.01 ) have also been reported by Táborsky et al. (19). In contrast, Moore et al. (18) and Durozard et al. (21) have described a normal resting muscle bioenergetic status in CRF patients. It is of note that Park et al. (20) reported a low $[\mathrm{PCr}] /[\mathrm{Pi}]$ ratio in CRF patients pre-rHuEPO followed by an increase after rHuEPO therapy, from $6.1 \pm 1.1$ to $8.7 \pm 2.1$, which has not been confirmed in the present study. Discrepancies among authors can likely be ascribed to technical factors and differences in the muscle groups explored.

Exercise protocol. We focused the study on the analysis of the relationships between muscle $\mathrm{O}_{2}$ transport and cellular bioenergetics at maximum exercise. Consequently, the exercise protocol was specifically designed to examine the performance above $70 \%$ whole-body $\dot{\mathrm{V}} \mathrm{O}_{2}$ peak. Recall that the percentages of maximal voluntary contraction (\%MVC), reported in Tables II and III, greatly exceed the corresponding percentages of whole-body $\dot{\mathrm{V}} \mathrm{O}_{2}$ peak. The marked changes in $\mathrm{pHi}$ throughout exercise observed in all the groups (Fig. 2, bottom right) might constrain the analysis of changes in $[\mathrm{PCr}] /[\mathrm{Pi}]$ ratio, \%[PCr] consumption, and half-time of $[\mathrm{PCr}]$ recovery as markers of mitochondrial oxidative capacity. The latter is often explored using submaximal exercise protocols that provoke negligible changes in $\mathrm{pHi}$. To cope with this potential limitation in the interpretation of the results, the ${ }^{31} \mathrm{P}-\mathrm{MRS}$ data were also expressed as a function of $\mathrm{pHi}$, as indicated in Fig. 3 and discussed below. An interesting finding of the present study is the strong correlation between femoral venous $\mathrm{pH}$ and $\mathrm{pHi}$ in the three groups (Fig. 4). Moreover, to reach high intensity levels of exercise, the protocol was set at 100 cycles $\times$ $\mathrm{min}^{-1}$ which, in turn, precluded the analysis of the spectra during the leg movements. As indicated in Methods, the PCr and $\mathrm{Pi}$ data were extrapolated to time 0 after each work load, and the derived variables $([\mathrm{PCr}] /[\mathrm{Pi}]$ ratio, \%[PCr] consumption and half-time of $[\mathrm{PCr}]$ recovery) were obtained from $\left[\mathrm{PCr}_{\mathrm{t} 0}\right]$ and $\left[\mathrm{Pi}_{\mathrm{t} 0}\right]$. Both the correlation of the measured data to a monoexponential function, as shown in Fig. 1, and indeed the consistency of the ${ }^{31} \mathrm{P}$-MRS data during exercise indicate that the 
characteristics of the protocol allowed for the analysis of the relationships between $\mathrm{O}_{2}$ supply and cellular bioenergetics in the setting.

Effects of rHuEPO on muscle cell bioenergetics during exercise. The analysis of submaximal and peak exercise data (Fig. 2) clearly shows that $[\mathrm{PCr}] /[\mathrm{Pi}]$ ratio and \%[PCr] consumption, at a given $\mathrm{VO}_{2} \mathrm{leg}$, did not change after rHuEPO. Intracellular $\mathrm{pH}$ and half-time of [PCr] recovery also did not show significant changes. The lack of effects of rHuEPO on the ${ }^{31} \mathrm{P}-\mathrm{MRS}$ data, at a given $\mathrm{VO}_{2}$ leg, suggests that either: (a) biochemical pathways (i.e., mitochondrial oxidative capacity) not related to $\mathrm{O}_{2}$ supply to the cell may determine the bioenergetic status of the muscle cells in these patients; or $(b)$ that $\mathrm{rHuEPO}$, despite the marked increase in [Hb] (by 50\%), did not effectively increase maximal $\mathrm{O}_{2}$ flow to the myocytes. The latter is the most likely explanation for the ${ }^{31} \mathrm{P}-\mathrm{MRS}$ data depicted in Fig. 2 as described above. The lack of changes in muscle $\mathrm{O}_{2}$ transport after $\mathrm{rHuEPO}$ are consistent with this notion. Moreover, since $\mathrm{O}_{2}$ supply dependency of maximum $\mathrm{O}_{2}$ uptake in CRF patients was demonstrated in the companion study (10), a reduced oxidative capacity appears unlikely to explain the lack of changes in muscle cell bioenergetics after rHuEPO. Thompson et al. (18) have reported ${ }^{31} \mathrm{P}-\mathrm{MRS}$ data measured in three CRF patients studied pre- and postrHuEPO therapy. These authors suggest that both impaired muscle $\mathrm{O}_{2}$ transport and limited mitochondrial oxidative capacity play a role limiting maximum exercise performance in these patients. However, the lack of a parallel assessment of muscle $\mathrm{O}_{2}$ transport in their study limits the interpretation of their results.

In summary, the present study confirms that: (a) reduction in muscle blood flow and (b) abnormal intramuscular $\mathrm{O}_{2}$ transport due to functional and structural derangement of muscle microcirculation provoked by uremic myopathy can explain the poor peak $\dot{\mathrm{V}} \mathrm{O}_{2}$ leg response after rHuEPO therapy. The lower $\mathrm{pHi}$, at a given $\dot{\mathrm{V}} \mathrm{O}_{2} \mathrm{leg}$, seen in CRF patients compared to controls, may be also partially explained by the low capillarity associated to uremic myopathy. This low pHi seems to account for the lower [PCr]/[Pi] ratio and the longer half-time of $\{\mathrm{PCr}]$ recovery, at a given $\dot{\mathrm{V}} \mathrm{O}_{2} \mathrm{leg}$, seen in these patients. However, derangement of the cytosolic regulation of oxidative phosphorylation directly provoked by uremic myopathy can not be ruled out.

\section{Acknowlegments}

The authors thank Felip Burgos, Conxi Gistau, Teresa Lecha, Maite Simó, and Carmen Argaña (Lung Function Laboratory) for their outstanding technical support; C Santos, M.D. (Urugüay) for her assistance in the studies; and Lluis de Jover, M.D. for his statistical assistance. The Centre d'Alt Rendiment (CAR) de Sant Cugat del Vallés and the Sandoz Sport Research Project allow us to use the ergometer. We are also grateful to the patients, the dialysis centers and the Registre de Malalts Renals de la Generalitat de Catalunya for their enthusiastic collaboration in the study.

Supported by grants FIS 92-0318 and 94-1106 from the Fondo de Investigaciones Sanitarias, Comissionat per Universitats i Recerca de la Generalitat de Catalunya (GRQ 94-9103), and HL-17731 from the National Heart, Lung and Blood Institute. Ramon M. Marrades was a research fellow supported by the Hospital Clínic (1993); Orlando Diaz was a research fellow supported by the Universidad Pontificia Católica de Chile; and Joan R. Masclans was a research fellow supported by the Fondo de Investigaciones Sanitarias (BAE 94/5176).
Peter D. Wagner was a visiting professor (PVI) at the University of Barcelona (1995-1996).

\section{References}

1. Eschbach, J.W., J.C. Egrie, M.R. Downing, J.K. Browne, and J.W. Adamson. 1987. Correction of the anemia of end-stage renal disease with recombinant human erythropoietin. N. Engl. J. Med. 316:73-78.

2. Eschbach, J.W., J. Mladenovic, J.F. Garcia, P.W. Wahl, and J.W. Adamson. 1984. The anemia of chronic renal failure in sheep: response to erythropoietin-rich plasma in vivo. J. Clin. Invest. 74:434-441.

3. Eschbach, J.W., and J.W. Adamson. 1988. Recombinant human erythropoietin: implications for nephrology. Am. J. Kidney Dis. 11:203-209.

4. Canadian Erythropoietin Study Group. 1990. Association between recombinant human erythropoietin and quality of life and exercise capacity of patients receiving haemodyalisis. Br. Med. J. 300:573-578.

5. Macdougall, I.C., N.P. Lewis, M.J. Saunders, D.L. Cochlin, M.E. Davies, R.D. Hutton, K.A.A. Fox, G.A. Coles, and J.D. Williams. 1990. Long-term cardiorespiratory effects of amelioration of renal anaemia by erythropoietin. Lancet. 335:489-493.

6. Robertson, H.T., N.R. Haley, M. Guthrie, D. Cardenas, J.W. Eschbach, and J.W. Adamson. 1990. Recombinant erythropoietin improves exercise capacity in anemic hemodialysis patients Am. J. Kidney Dis. 15:325-332.

7. Satoh, K., T. Masuda, Y. Ikeda, S.H. Kurokawa, K. Kamata, R. Kikawada, T. Takamoto, and F. Marumo. 1990. Hemodynamic changes in recombinant erythropoietin therapy in hemodialyzed patients. Hypertension (Dallas). 15:262-266.

8. Metra, M., G. Cannella, G. La Canna, T. Guaini, M. Sandrini, M. Gaggiotti, E. Movilli, and L. Dei Cas. 1991. Improvement in exercise capacity after correction of anemia in patients with end-stage renal failure. Am. J. Cardiol. 68: 1060-1066.

9. Davenport, A. 1993. The effect of treatment with recombinant human erythropoietin on skeletal muscle function in patients with end-stage renal failure treated with regular hospital hemodialysis. Am. J. Kidney Dis. 22:685-690.

10. Marrades, R.M., J. Roca, J. Campistol, O. Diaz, J.A. Barberà, J.V. Torregrosa, J.R. Masclans, A. Cobos, R. Rodriguez-Roisin, and P.D. Wagner. 1996. Effects of erythropoietin therapy on muscle $\mathrm{O}_{2}$ transport in patients with chronic renal failure. J. Clin. Invest. 1996. 97:2092-2100.

11. Bradley, J.R., J.R. Anderson, D.B. Evans, and A.J. Cowley. 1990. Impaired nutritive skeletal muscle blood flow in patients with chronic renal failure. Clin. Sci. 79:239-245.

12. Moore, G.E., B. Parsons, J. Stray-Gundersen, P.L. Painter, K.R. Brinker, and J.H. Mitchell. 1993. Uremic myopathy limits aerobic capacity in hemodialysis patients. Am. J. Kidney Dis. 22:277-287.

13. Diesel, W., M. Emms, B.K. Knight, T.D. Noakes, R. van Zyl Smit, R.O.C. Kaschula, and C.C. Sinclair-Smith. 1993. Morphologic features of the myopathy associated with chronic renal failure. Am. J. Kidney Dis. 22:677-684.

14. Piiper, J., and P. Scheid. 1981. Model for capillary alveolar equilibration with special reference to $\mathrm{O}_{2}$ uptake in hypoxia. Respir. Physiol. 46:193-208.

15. Wagner, P.D. 1993. Algebraic analysis of the determinants of $\dot{\mathrm{V}}_{2}$ max. Respir. Physiol. 93:221-237.

16. Roca, J., A.G.N. Agustí, J. Alonso, D.C. Poole, C. Viegas, J.A. Barberà, R. Rodriguez-Roisin, A. Ferrer, and P.D. Wagner. 1992. Effects of training on muscle $\mathrm{O}_{2}$ transport at $\mathrm{VO}_{2} \max$. J. Appl. Physiol. 73:1067-1076.

17. Painter, P., and G.E. Moore. 1994. The impact of recombinant human erythropoietin on exercise capacity in hemodialysis patients. Adv. Renal Replacement Therapy. 1(1):55-65.

18. Moore, G.E., L.A. Bertocci, and P.L. Painter. 1993. ${ }^{31}$ P-magnetic resonance spectroscopy assessment of subnormal oxidative metabolism in skeletal muscle of renal failure patients. J. Clin. Invest. 91:420-424.

19. Thompson, C.H., G.J. Kemp, D.J. Taylor, J.G. Ledingham, G.K. Radda, and B. Rajagopalan. 1993. Effect of chronic uraemia on skeletal muscle metabolism in man. Nephrol. Dial. Transplant. 8:218-222.

20. Park, J.S., S.B. Kim, S.K. Park, T.H. Lim, D.K. Lee, and C.D. Hong. 1993. Effect of recombinant human erythropoietin on muscle energy metabolism in patients with end-stage renal disease: ${ }^{31} \mathrm{P}$-nuclear magnetic resonance spectroscopic study. Am. J. Kidney Dis. 21:612-618.

21. Durozard, D., P. Pimmel, S. Baretto, A. Cailette, M. Labeeuw, G. Baverel, and P. Zech. 1993. ${ }^{31} \mathrm{P}-\mathrm{NMR}$ spectroscopy investigation of muscle metabolism in hemodialysis patients. Kidney Int. 43:885-892.

22. Táborsky, P., I. Sotorník, J. Kaslikova, O. Schük, M. Hájek, and A. Horská. 1993. ${ }^{31}$ P-magnetic resonance spectroscopy investigation of skeletal muscle metabolism in uraemic patients. Nephron. 65:222-226.

23. Roca, J., J. Sanchis, A. Agustí-Vidal, F. Segarra, D. Navajas, R. Rodriguez-Roisin, P. Casan, and S. Sans. 1986. Spirometric reference values from a mediterranean population. Bull. Eur. Physiopath. Respir. 22:217-224.

24. Gonzalez de Suso, J.M., G. Bernús, J. Alonso, A. Alay, A. Capdevila, J. Gili, J.A. Prat, and C. Arús. 1993. Development and characterization of an ergometer to study the bioenergetics of the human quadriceps muscle by ${ }^{31} \mathrm{P}$ NMR spectroscopy inside a standard NMR scanner. Magn. Reson. Med. 29: $575-581$. 
25. Taylor, D.J., P.J. Bore, P. Stylen, D.G. Gadian, and G.K. Radda. 1983. Bioenergetics of intact human muscle. A ${ }^{31} \mathrm{P}$-nuclear magnetic resonance study. Mol. Biol. Med. 1:77-94.

26. Agustí, A.G.N., J. Roca, J.A. Barberà, J. Casademont, R. RodriguezRoisin, and P.D. Wagner. 1994. Effect of sampling site on femoral venous blood gas values. J. Appl. Physiol. 77:2018-2022.

27. Deleted in proof

28. McCully, K.K., S. Iotti, K. Kendrick, Z. Wang, J.D. Posner, J. Leigh, and B. Chance. 1994. Simultaneous in vivo measurements of $\mathrm{HbO}_{2}$ saturation and PCr kinetics after exercise in normal humans. J. Appl. Physiol. 77:5-10.

29. Kemp, G.J., D.J. Taylor, and G.K. Radda. 1993. Control of phosphocreatine resynthesis during recovery from exercise in human skeletal muscle. NMR Biomed. 6:66-72.

30. Kemp, G.J. and G.K. Radda. 1994. Quantitative interpretation of bioenergetic data from ${ }^{31} \mathrm{P}$ and ${ }^{1} \mathrm{H}$ magnetic resonance spectroscopic studies of skeletal muscle: an analytical review. Magn. Res. Q. 10(1):43-63.

31. Iotti, S., R. Lodi, C. Frassineti, P. Zaniol, and B. Barbiroli. 1993. In vivo assessment of mitochondrial functionality in human gastrocnemius muscle by ${ }^{31}$ P-MRS. NMR Biomed. 6:248-253.

32. Wagner, P.D., J. Roca, M.C. Hogan, D.C. Poole, D.E. Bebout, and P.
Haab. 1990. Experimental support for the theory of diffusion limitation of maximum oxygen uptake. In $\mathrm{O}_{2}$ Transport to Tissue XII. J. Piiper, T.K. Goldstick, and M. Meyer, editors. New York, Plenum Press. 825-833.

33. Bohr, C. 1909. Uber die spezitische Tatigkeit der Lungen bei der Respiratorischen Gasaufnahme und ihr Verhalten zu der durch die Alveolarwand stattfindenden Gasdiffusion. Scand. Arch. Physiol. 22:221-280.

34. Roca, J., M.C. Hogan, D.C. Story, D.E. Bebout, P. Haab, R. Gonzalez, O. Ueno, and P.D. Wagner. 1989. Evidence for tissue diffusion limitation of $\mathrm{V} \mathrm{O}_{2} \max$ in normal humans. J. Appl. Physiol. 67:291-299.

35. Wagner, P.D. 1977. Diffusion and chemical reaction in pulmonary gas exchange. Physiol. Rev. 57:257-312.

36. Bernús, G., J.M. Gonzalez de Suso, J. Alonso, P.A. Martin, J.A. Prat, and C. Arús. 1993. ${ }^{31} \mathrm{P}-\mathrm{MRS}$ of quadriceps reveals quantitative differences between sprinters and long-distance runners. Med. Sci. Sports Exerc. 25:479-484.

37. Bendahan, D., S. Confort-Gouny, G. Kozak, and P.J. Cozzone, 1993. Investigation of metabolic myopathies by ${ }^{31} \mathrm{P}-\mathrm{MRS}$ using a standardized restexercise-recovery protocol: a survey of 800 explorations. MAGMA. 1:91-104.

38. Taylor, D.J., B. Rajagopalan, and G.K. Radda. 1992. Cellular energetics in hypothyroid muscle. Eur. J. Clin. Invest. 22:358-365. 